WellBeing International

WBI Studies Repository

$5-1-2016$

\title{
Efficiency of the Male Effect with Photostimulated Bucks Does Not Depend on their Familiarity with Goats
}

\author{
A. L. Muñoz \\ Universidad Autónoma Agraria Antonio Narro \\ M. Bedos \\ Universidad Autónoma Agraria Antonio Narro \\ R. M. Aroña \\ Universidad Autónoma Agraria Antonio Narro \\ J. A. Flores \\ Universidad Autónoma Agraria Antonio Narro \\ H. Hernández \\ Universidad Autónoma Agraria Antonio Narro
}

See next page for additional authors

Follow this and additional works at: https://www.wellbeingintlstudiesrepository.org/repbeh

Part of the Animal Studies Commons, Behavior and Ethology Commons, and the Comparative

Psychology Commons

\section{Recommended Citation}

Muñoz, A. L., Bedos, M., Aroña, R. M., Flores, J. A., Hernández, H., Moussu, C., ... \& Delgadillo, J. A. (2016). Efficiency of the male effect with photostimulated bucks does not depend on their familiarity with goats. Physiology \& behavior, 158, 137-142.

This material is brought to you for free and open access by WellBeing International. It has been accepted for inclusion by an authorized administrator of the WBI Studies Repository. For more information, please contact wbisr-info@wellbeingintl.org.

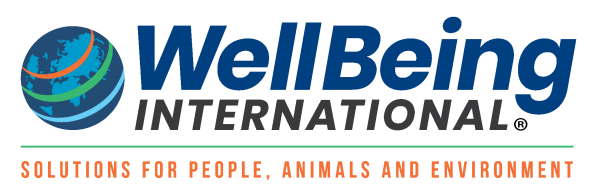




\section{Authors}

A. L. Muñoz, M. Bedos, R. M. Aroña, J. A. Flores, H. Hernández, C. Moussu, Elodie F. Briefer, P. Chemineau, M. Keller, and J. A. Delgadillo 


\title{
Efficiency of the Male Effect with Photostimulated Bucks Does Not Depend on their Familiarity with Goats
}

\author{
A.L. Muñoz ${ }^{1}$, M. Bedos ${ }^{1}$, R.M. Aroña ${ }^{1}$, J.A. Flores ${ }^{1}$, H. Hernández ${ }^{1}$, C. Moussu², E.F. Briefer ${ }^{3}$, P. \\ Chemineau $^{2}$, M. Keller ${ }^{2}$, J.A. Delgadillo ${ }^{1}$ \\ ${ }^{1}$ Universidad Autónoma Agraria Antonio Narro \\ ${ }^{2}$ University of Tours \\ ${ }^{3}$ ETH Zürich
}

\section{KEYWORDS}

social recognition, familiarity, male effect, anovulatory goats, ovulation, photoperiodic treatment

\begin{abstract}
In ewes, the ovulatory response of females exposed to familiar rams is lower than the response of those exposed to novel ones. In goats, males rendered sexually active by exposure to long days are more efficient to induce ovulation in seasonal anestrous females than untreated males. Two experiments were conducted to determine 1) whether male goats remain familiar to females after 45 days of separation; and 2) whether photostimulated males are able to stimulate the sexual activity of females, independently of their familiarity with them. In Experiment 1, three groups of goats ( $n=10$ goats per group) were put in contact with males ( $\mathrm{n}=2$ per group) during 10 days in November (familiarization period). These males were called familiar males. After 15, 30 and 45 days of separation from the males, females of each group were exposed to familiar or novel males during $10 \mathrm{~min}$. In each test, goats in contact with novel males displayed more distress bleats, escapes, head butts, and sniffing than those in contact with familiar males $(P<0.05)$. In Experiment 2, we used sexually inactive ( $n=4$ control males), and sexually active males ( $n=4$ photostimulated males). In February, two groups of goats ( $n=50$ each) were put in contact with control or photostimulated males $(n=2$ each) during 10 days ("familiar" control or photostimulated male, respectively). After 45 days of separation from the males, both groups of females were further divided into two groups ( $n=25$ goats per group). In April, two groups were re-exposed to "familiar" control or "familiar" photostimulated males ( $n=2$ per group), whereas the other two groups were exposed to "novel" control or "novel" photostimulated males ( $n=2$ per group). The photostimulated males displayed a higher level of sexual behavior than the controls. The proportion of goats that ovulated and displayed estrus was higher when exposed to the photostimulated males than when exposed to control ones ( $\geq 80 \%$ vs. $0 \%$; $P<0.05$ ). These proportions did not differ between groups exposed to familiar or novel photostimulated males $(P<0.05)$. We concluded that after 45 days of separation, males are still familiar to females. The photostimulated males are able to induce the sexual activity of seasonally anestrous goats independently of their familiarity with them.
\end{abstract}




\section{Introduction}

In breeds of goats and ewes that display reproductive seasonality, the introduction of a male into a group of seasonal anovulatory females induces an immediate increase in the secretion of $\mathrm{LH}$, leading to ovulation associated or not with estrous behavior. This phenomenon is known as the "male effect" [1-3]. Many factors influence the endocrine and ovulatory responses of females exposed to males, among which are the intensity of the male's sexual behavior, the degree of familiarity with males, and the previous period of separation between sexes.

In small ruminant females showing a strong seasonality, the endocrine and sexual changes associated with the male effect are low or absent in most females during the mid-anestrus, probably due to a decrease of the sexual behavior of males that are also in sexual rest [4-6]. However, when bucks are submitted to artificial long days followed by natural photoperiod to stimulate their sexual behavior during the natural sexual rest, these males become able to stimulate the secretion of $\mathrm{LH}$, estrous behavior and ovulation in most anestrous females [7-9]. These results suggest that the intensity of sexual behavior of males is an important factor for the success of the male effect.

Another factor that could modify the effectiveness of the male effect is the use of "familiar males", i.e. males already known by females. Indeed, different studies suggest that familiarity plays an important role in social recognition. In fact, it was demonstrated that goats are able to recognize group members relying on olfactory and visual cues [10]. Interestingly, in sheep, females are able to remember familiar individuals over very long periods of time (>2 months; [11]). In addition, Keller et al. [12] demonstrated that ewes were able to recognize familiar flock partners in comparison to a completely unfamiliar female after only $24 \mathrm{~h}$ of direct contact. More interestingly, it was shown that the endocrine response of females is higher when they are exposed to novel males in comparison to familiar ones. Indeed, when ewes were exposed for 3 months to males (familiar males), and re-exposed to familiar or novel males after 15 min of separation during the anestrus season, only the novel males were able to increase the frequency of LH pulses [13]. In another study, females remained with males during 3 months, and were then re-exposed to them (familiar males) or exposed to novel males after 15 min or 1 month of separation [14]. This study demonstrated that novel rams increase the pulsatile LH secretion and stimulate LH surge in all females after either $15 \mathrm{~min}$ or 1 month of separation, whereas familiar ones are able to increase pulsatile LH secretion only after 1 month of separation and stimulate a preovulatory LH surge in only a third of females [14]. Overall, these results suggest that in ewes, the familiarity of males plays an important role in the response of females to males. In addition, these results suggest that familiar males may become novel again after about 1 month of separation of females.

For decades, it has been thought that females must be previously isolated from males to respond to the male effect. In ewes, it was shown that periods of 21 or 17 days of isolation were sufficient to ensure an ovulatory response in females exposed to males [15,16]. Furthermore, Cohen-Tannoudji and Signoret [17] found that ewes showed an increase of LH pulsatility when they were re-exposed to males after $24 \mathrm{~h}$ of separation. Similarly, in goats, it was suggested that a period of at least 3 weeks of separation between sexes was necessary so that females were able to display the male effect [2]. However, it was demonstrated that previous separation between sexes is not necessary when males are naturally sexually active or stimulated by exposure to artificially long days $[18,19]$. In fact, in one of these studies, most females (9/11) that remained during about three months with sexually inactive males due to the seasonal quiescence, displayed estrous behavior and ovulated when they were re-exposed to photostimulated bucks. In contrast, no females displayed estrous behavior and only 1/11 female ovulated when they were re-exposed to another sexually inactive buck [19]. These later results suggest that the sexual behavior of males plays an important role in inducing the sexual activity of does. However, it is 
difficult to interpret the results reported by Véliz et al. [19], because the study does not mention if the sexually active or inactive males that were re-introduced with females were familiar or novel bucks.

Considering that photostimulated bucks are very efficient in inducing the sexual activity of seasonally anestrous females, we hypothesized that sexually active bucks would be able to stimulate the estrus and ovulatory activities of females, independently of their familiarity with them. To test this possibility, we exposed females in seasonal anestrus to a 10-days period of "familiarization" with males that were either subjected to a photoperiodic treatment or kept under natural photoperiod, and re-exposed them to either a familiar or novel male after 45 days of separation.

\section{Materials and methods}

\subsection{General}

The procedures used in this experiment were in strict accordance with the Official Mexican Rule for the technical specifications for the production, care, and use of laboratory animals [20].

This study was conducted during the non-breeding season using local goats from Laguna Region at the State of Coahuila, Mexico (latitude $26^{\circ} 23^{\prime} \mathrm{N}$, longitude $104^{\circ} 47^{\prime} \mathrm{W}$ ). The photoperiod in this region varies from $13 \mathrm{~h} 41 \mathrm{~min}$ of light at the summer solstice to $10 \mathrm{~h} 19 \mathrm{~min}$ of light at the winter solstice. The seasonal anestrus in females isolated from males occurs from February-March to August-September; the sexual rest in bucks isolated from females occurs from December-January to May-June [21,22]. During the whole study, females and males were fed with $2 \mathrm{~kg}$ of alfalfa hay (18\% CP) and $200 \mathrm{~g}$ of commercial concentrate feed $(14 \% \mathrm{CP} ; 1.7 \mathrm{Mcal} / \mathrm{kg})$ with free access to water and mineral blocks.

\subsection{Experiment 1}

\subsubsection{Females and familiarization period}

On November 15th, female goats were divided in three groups $(\mathrm{n}=10$ each), and kept in three, $10 \times 10$ $\mathrm{m}$, different shaded open pens. The distance between pens was at least $100 \mathrm{~m}$. On November 20th, the females of each group were put in direct physical contact with males $(n=2)$ and remained with them during 10 days. The aim of this procedure was that males become "familiar" to females. After the 10-days period of contact, on November 30th, males were removed from the three groups of females and put in another pen located at least $200 \mathrm{~m}$ from the pens of females. Females of each group remained together until the recognition tests were performed.

\subsubsection{Measurements}

With the aim to prove that females are able to recognize males after a previous separation period of 15 , 30 and 45 days, we used the paired closed encounters test, which has been previously used to test the discrimination between familiar or novel individuals in sheep [23,12]. Each doe was individually tested in two stages: for half of the females, the test was performed first with a familiar male and second with a novel male. By contrast, the other half of the females was tested first with a novel male and second with a familiar male. The time between the first test and the second test was around $2 \mathrm{~h}$. Before starting the test, each doe was removed from its pen and introduced into an independent pen test $(2 \times 2 \mathrm{~m})$ during $2 \mathrm{~min}$. After this period, one "familiar" or "novel" male (no prior contact with females) was introduced during 10 min and the following behaviors displayed by the doe were scored; the number of distress bleats, escapes, head butts, and sniffing. After the tests, each doe was placed in a new independent pen with the aim of avoiding the transmission of smell of the male to the other females. 


\subsubsection{Statistical analyses}

The Wilcoxon Signed-Rank test was used to compare the behaviors displayed by each female in presence of familiar or novel males within each test. The Kruskal-Wallis test was used to compare the behaviors displayed by females in presence of familiar or novel males between each test.

\subsection{Experiment 2}

\subsubsection{Stimulation of sexual behavior of males}

We used eight adult bucks that had never been in contact with the females used in this experiment (see Section 2.3.3). Four bucks were kept under natural variations of day-length during the whole experiment. These males were the control males. Another four adult male goats were subjected in a $10 \mathrm{~m} \times 5 \mathrm{~m}$ shaded open pen to a photoperiodic treatment to induce their sexual activity during the non-breeding season as described previously [24]. These bucks were the photostimulated males. Briefly, males were exposed to artificial long days ( $16 \mathrm{~h}$ of light/8 $\mathrm{h}$ of darkness) from November 1st to January 15th. From January 16th on, males were exposed to natural variations of day-length until the end of the study. This photoperiodic treatment stimulates testosterone secretion in March and April and, as a consequence, improves the intensity of sexual behavior and odor during the months corresponding to the non-breeding season [24,25].

\subsubsection{Females and familiarization period}

On January 27th, non-pregnant female goats were divided in two groups balanced for body condition score (BCS; [26]) and kept in two different, $10 \times 10 \mathrm{~m}$, shaded open pens. On February 3rd, one group of does ( $n=50$; BCS: $2.0 \pm 0.2$; mean \pm SEM) was put in direct physical contact with the control males $(n=$ $2)$, whereas another group of does $(n=50$; BCS: $2.1 \pm 0.1)$ was put in direct physical contact with the photostimulated males $(n=2)$. The distance between these pens was about $100 \mathrm{~m}$. The photostimulated males were put in contact with the does 19 days after the end of the photoperiodic treatment, when they were still sexually quiescent, and the control males were already in sexual rest [24]. The contact between females and males lasted 10 days, in order to expose both groups of females to sexually inactive males. On February 13th, control and photostimulated males were removed from both groups of does. Females from both groups remained together in their respective open pens until the males were re-introduced (see below). The objective of this pre-exposure period was that control and photostimulated males became "familiar" to does $[11,12]$. Thereafter, the males used during the familiarization period were called familiar control or familiar photostimulated males.

\subsubsection{The male effect}

On March 14th, 21st and 28th, all the multiparous goats $(n=100)$ exposed in February to control or photostimulated males were submitted to a transrectal ultrasonography to determine their ovarian cyclicity using an Aloka SSD-500 scanner connected to a transrectal $7.5 \mathrm{MHz}$ linear probe. None of the females presented corpus luteum. Therefore, all of them were considered in seasonal anovulation. On March 28th, the two groups of goats were further divided ( $n=25$ each) according to their BCS: goats exposed in February to control males were divided in two groups. Thereafter, on April 2nd (day 0 at 08:00), one group (BCS: $1.9 \pm 0.1)$ was re-exposed to the "familiar" control males $(n=2)$, whereas the other one (BCS: $1.9 \pm 0.3)$ was exposed to the "novel" control males $(n=2)$. Females previously exposed to the photostimulated males were also divided in two groups: one group (BCS: $1.9 \pm 0.3$ ) was re-exposed to the "familiar" photostimulated males $(n=2)$, whereas the other one (BCS: $1.9 \pm 0.1)$ was exposed to the "novel" photostimulated males $(n=2)$. Each group of females exposed to males was divided into two subgroups so that each buck individually stimulated 12 or 13 females. The four groups of females remained 
in contact with their respective males for 18 days. The distance between the four groups of females was about $100 \mathrm{~m}$ to prevent any visual or auditory contact between groups.

\subsubsection{Measurements}

To ensure that bucks used in this experiment displayed levels of sexual behavior corresponding to their respective group, sexual behavior was individually recorded for $1 \mathrm{~h}$ by trained observers, from 08:00 to 09:00, on day 0 and 1 following their introduction into the groups of females. One hour of observation in the first two days after male introduction allowed to discriminate the differences in sexual behavior between the sexually active and inactive male goats $[27,28]$. The following behaviors were recorded; nudging, ano-genital sniffing, mount intention movements, self-urination and flehmen [5,29,30].

Fig. 1. Number of behaviors (mean \pm SEM) displayed by female goats individually exposed during 10 min to "novel" (-) or "familiar" ( $\square$ ) bucks after 45 days (A), 30 days (B) or 15 days (C) of separation. Prior to the tests, females of each group remained in contact with males $(n=2)$ during 10 days (familiarization period). These were called the "familiar males" ( $\left.{ }^{\star} \mathrm{P}<0.05\right)$.

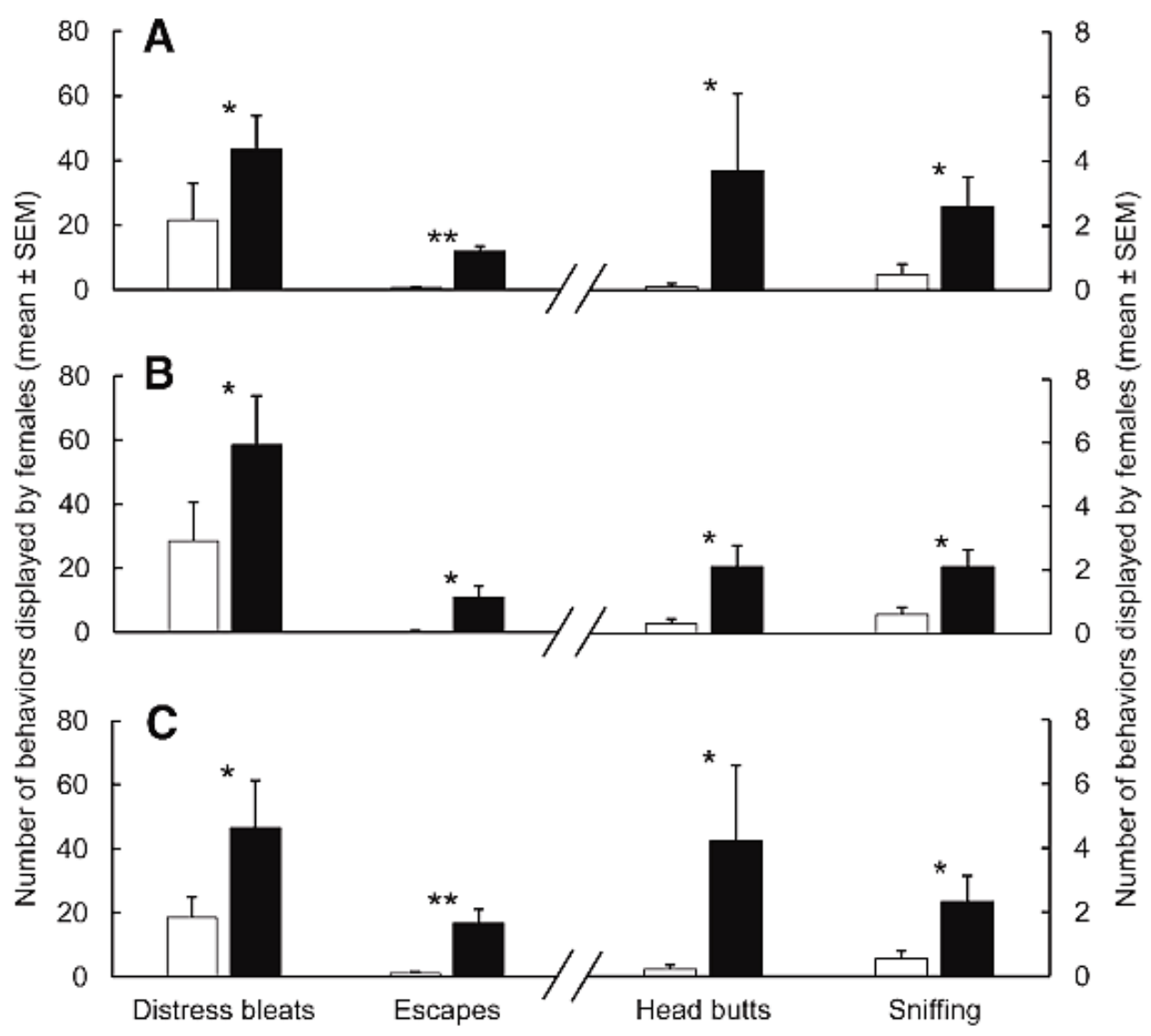

The ovarian activity was assessed by the presence of corpora lutea observed in each female by transrectal ultrasonography 6 and 19 days after the introduction of males using the same equipment (see Section 2.3.3). In addition, the presence of corpora lutea was confirmed by progesterone levels. For this aim, blood samples were obtained daily from each female from day 0 to day 9 and every 3 days from day 
12 to day 18 after the introduction of males. All 5-mL samples were collected by jugular venipuncture in tubes containing $30 \mu \mathrm{L}$ of heparin and centrifuged immediately at $3500 \times \mathrm{g}$ for $30 \mathrm{~min}$; the obtained plasma was stored at $-20{ }^{\circ} \mathrm{C}$ until progesterone concentrations were measured by immunoenzymatic assay as described by Canépa et al. [31]. Sensitivity was $0.25 \mathrm{ng} / \mathrm{mL}$. The intra- and inter-assay coefficients of variation were 8 and $10 \%$, respectively. Females in which progesterone increased to $\geq 1.0$ $\mathrm{ng} / \mathrm{mL}$ were considered to have ovulated [32].

Estrous behavior of females was monitored twice daily (between 08:00 and 09:00 and between 18:00 and 19:00) during the 18 days of the study. A female was considered in estrus if she stood immobile when mounted by the male [33]. A high percentage of female goats displayed short estrous cycles when exposed to the sexually active males. Therefore, in this study, the percentage of these cycles and their duration were inferred from the monitoring of estrus, and duration was defined as the number of days between the beginnings of two consecutive estruses. Duration of short estrous cycle is <17 days [33]. In females that displayed short estrous cycles, the estrus-ovulation association was determined at first and second ovulation, whereas in females that displayed normal estrous cycles, this association was determined at the first ovulation. In both cases, results were reported as the percentage of females that displayed estrus accompanied by ovulation.

Fig. 2. Sexual behavior of males. Individual values of mean occurrences of nudging, ano-genital sniffing, mounting attempts, self-urination and flehmen in males ( $n=2$ per group) interacting with seasonal anestrous goats. Familiar $(\bullet)$ or novel (०) control, sexually inactive males, were kept under natural variations of day-length during the whole experiment. Familiar ( $\square$ ) or novel $(\square)$ photostimulated males were rendered sexually active by exposure to artificial long days (16 $\mathrm{h}$ of light per day) from November 1st to January 15th followed by natural photoperiodic conditions. Sexual behavior of males was observed from 08:00 to 09:00 on day 0 and 1 following their introduction in the groups of females.

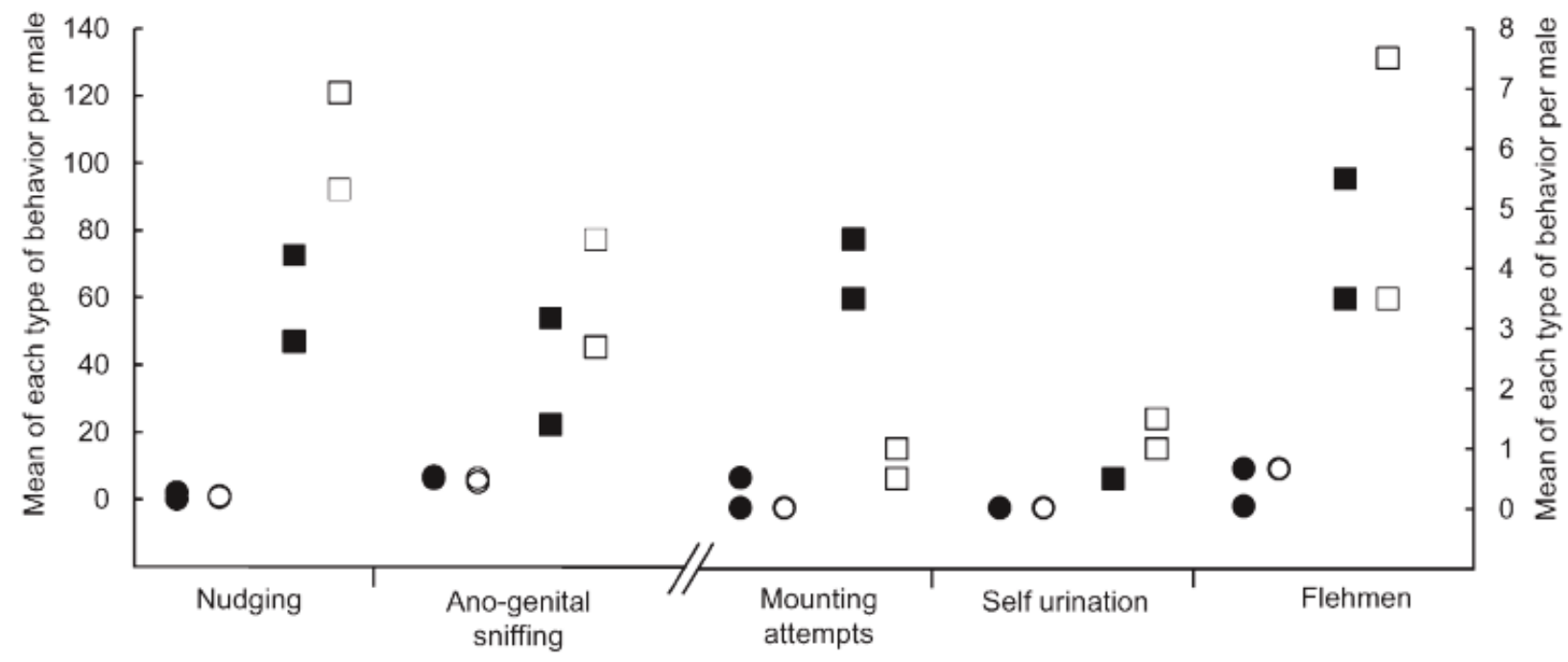

\subsubsection{Statistical analyses}

The percentages of females that showed estrous and/or ovulation, short or normal ovulatory cycles and the association between estrous and ovulation were compared by Chi-Square test. A two-sample t-test 
was used to assess statistical differences between the duration of short ovulatory cycles. Sexual behavior of bucks could not be statistically analyzed due to the low number of males in each group $(n=2)$.

Analyses were computed using the statistical package SYSTAT 13 [34]. Data were expressed as the mean \pm standard error of the mean and differences were considered significant at the level of $P \leq 0.05$.

Table 1.

Estrus and ovulatory responses of anestrous female goats exposed to familiar or novel control, sexually inactive males that were kept under natural variations of day-length, or exposed to familiar or novel photostimulated males rendered sexually active by exposure to long days (16 h of light per day) from November 1st to January 15th followed by natural photoperiodic conditions.

\begin{tabular}{|lccccc|}
\hline $\begin{array}{l}\text { Groups of females in contact } \\
\text { with: }\end{array}$ & $\mathbf{n}$ & $\begin{array}{c}\text { Females with } \\
\text { ovulations (\%) }\end{array}$ & $\begin{array}{c}\text { Females with } \\
\text { estrus (\%) }\end{array}$ & $\begin{array}{c}\text { Females with } \\
\text { normal estrous } \\
\text { cycles (\%) }\end{array}$ & $\begin{array}{c}\text { Females with } \\
\text { short estrous } \\
\text { cycles (\%) }\end{array}$ \\
\hline Familiar control males & 25 & $0^{\mathrm{a}}$ & $0^{\mathrm{a}}$ & $\begin{array}{c}\text { Duration of } \\
\text { short estrous } \\
\text { cycles (days) }\end{array}$ \\
Novel control males & 25 & $0^{\mathrm{a}}$ & $0^{\mathrm{a}}$ & -- & -- \\
Familiar photostimulated males & 25 & $96^{\mathrm{b}}$ & $80^{\mathrm{b}}$ & -- & -- \\
Novel photostimulated males & 25 & $96^{\mathrm{b}}$ & $80^{\mathrm{b}}$ & $23^{\mathrm{b}}$ & $73^{\mathrm{b}}$ \\
\hline
\end{tabular}

${ }^{\mathrm{a}, \mathrm{b}}$ Values with different letters within each column are different $(\mathrm{P}<0.05)$.

* The latency to first estrus and the duration of short ovarian cycles were expressed as the mean \pm standard error of the mean

\section{Results}

\subsection{Experiment 1}

\subsubsection{Behavior of females}

Goats in contact with novel males displayed more distress bleats, escapes, head butts, and sniffing at 15, 30 , and 45 days than those in contact with familiar males $(P<0.05$; Fig. 1). However, time did not affect the evolution of these variables between successive expositions $(P<0.05)$, suggesting a strong and longterm maintenance of this social recognition.

\subsection{Experiment 2}

\subsubsection{Sexual behavior of males}

Sexually active males seemed to display a higher level of sexual behavior than sexually inactive ones. Indeed, the occurrences of all the behaviors considered, including nudging, ano-genital sniffing, mounting attempts, self-urination and flehmen expressed by the photostimulated males were higher than those expressed by control ones (Fig. 2).

\subsubsection{Estrous and ovulatory responses of goats}

The proportion of goats that ovulated or showed estrous behavior at least once was higher in the groups exposed to familiar or novel photostimulated males, than in the groups exposed to familiar or novel control males ( $\mathrm{P}<0.05$; Table 1; Figs. 3 and 4). Indeed, during the whole study, none of the goats in contact with familiar or novel control males displayed estrous behavior or ovulation. In contrast, most goats exposed to familiar or novel photostimulated males showed estrous behavior ( $\geq 80 \%)$ and ovulated $(96 \%)$ at least once during the whole study. The proportion of females that showed estrous behavior or ovulated did not differ among groups exposed to familiar or novel photostimulated males $(P>0.05)$. In 
addition, the proportion of goats that displayed normal or short estrous cycles did not differ between groups ( $P>0.05$ ). Finally, in females exposed to familiar or novel photostimulated males and displaying short estrous cycles, the estrus ovulation association at the first $(75 \%$ vs. $70 \%)$ and second (100\% vs. $100 \%)$ ovulation did not differ between groups $(P>0.05)$. Similarly, in females exposed to familiar or novel photostimulated males displaying normal estrous cycles, the estrus-ovulation association (67\% vs. $100 \%)$ did not differ between groups $(P>0.05)$. After day 10 , no estrous behavior or ovulations were recorded (Fig. 3).

Fig. 3. Estral response of goats exposed to males. Daily percentages of females that displayed estrous behavior after introduction of familiar $(\boldsymbol{\square} ; n=25)$ or novel $(\square ; n=25)$ photostimulated males. None of the females exposed to familiar or novel control males showed estrous behavior and are therefore not represented in the figure. The photostimulated males were rendered sexually active by exposure to artificial long days ( $16 \mathrm{~h}$ of light per day) from November 1 st to January 15 th followed by natural photoperiodic conditions.

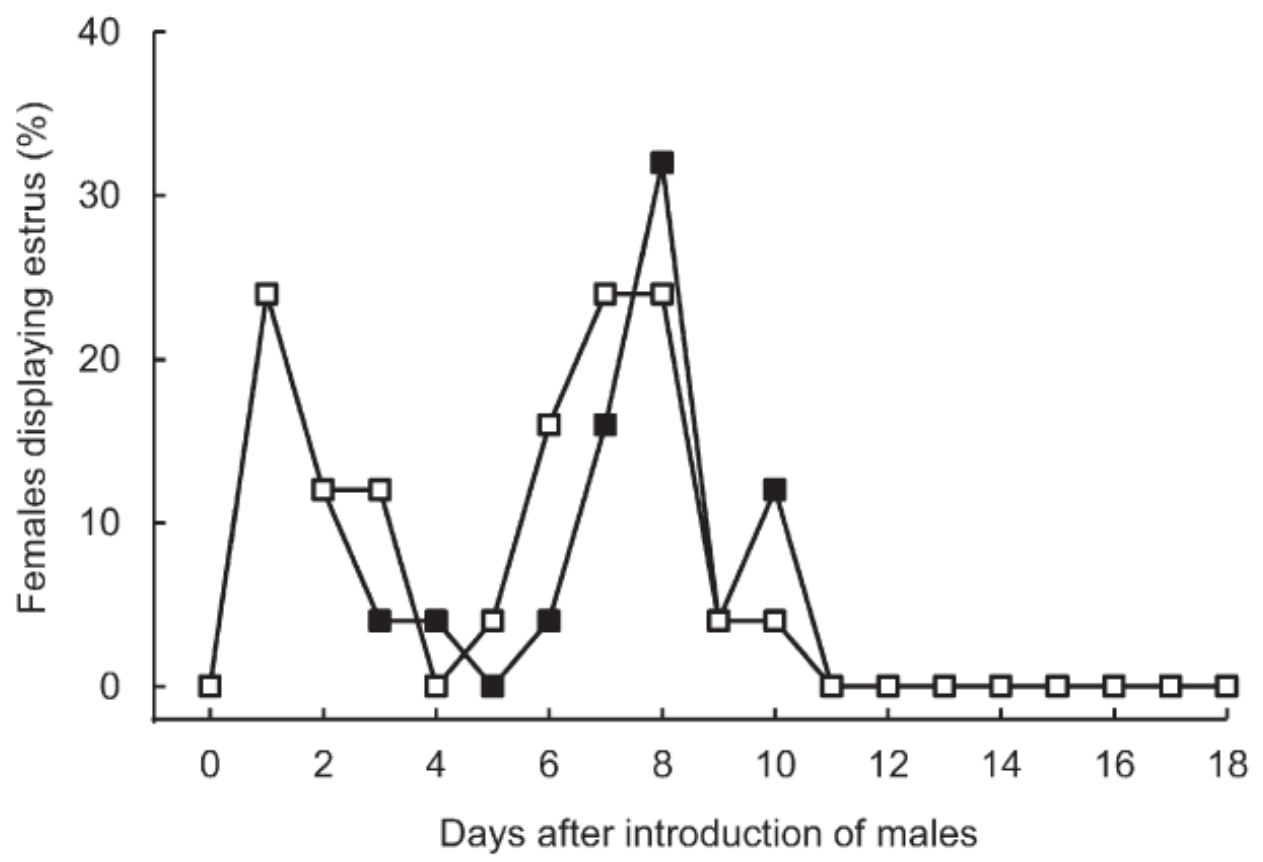

\section{Discussion}

The aim of this study was to determine whether males remain familiar to females after 45 days of separation, and to whether photostimulated males are able to stimulate the sexual activity of females, independently of their familiarity with them. Therefore, in this study we showed that males remain familiar to females after 45 days of separation, and that photostimulated bucks are able to induce sexual activity in seasonally anestrous goats, independently of whether they are "familiar" or "novel" males. Indeed, the percentages of females that displayed estrous behavior or ovulated when exposed to photostimulated males was high and did not differ between does exposed to the familiar or novel photostimulated males. In addition, the characteristics of the sexual responses to the introduction of males, such as the percentages of short or normal estrous cycles, and the duration of the short cycles did not differ between females in contact with the familiar or novel photostimulated males. In contrast, neither estrous behavior nor ovulations were observed in goats exposed to the familiar or novel control males. Our results are in accordance with previous studies that showed that photostimulated males are able to induce sexual 
activity in most females, whereas the control bucks are unable to do so in seasonally anestrous goats $[5,35,36]$. Taken together, these findings confirm our hypothesis that sexually active males are able to stimulate the sexual activity of female goats, independently of their familiarity with them. In addition, our results support the hypothesis that in goats, the sexual behavior of males is a key factor to stimulate the estrous and ovulatory activities of females subjected to the male effect.

Fig. 4. Representative profiles of plasma concentration of progesterone of goats exposed to males. Individual patterns of plasma progesterone concentration in goats exposed to familiar $(\bullet)$ or novel $(\circ)$ control, sexually inactive males, or to familiar ( $\square$ ) or novel ( $\square$ ) photostimulated males. The photostimulated males were rendered sexually active by exposure to artificial long days ( $16 \mathrm{~h}$ of light per day) from November 1st to January 15th followed by natural photoperiodic conditions. The bars indicate the duration of estrous behavior.

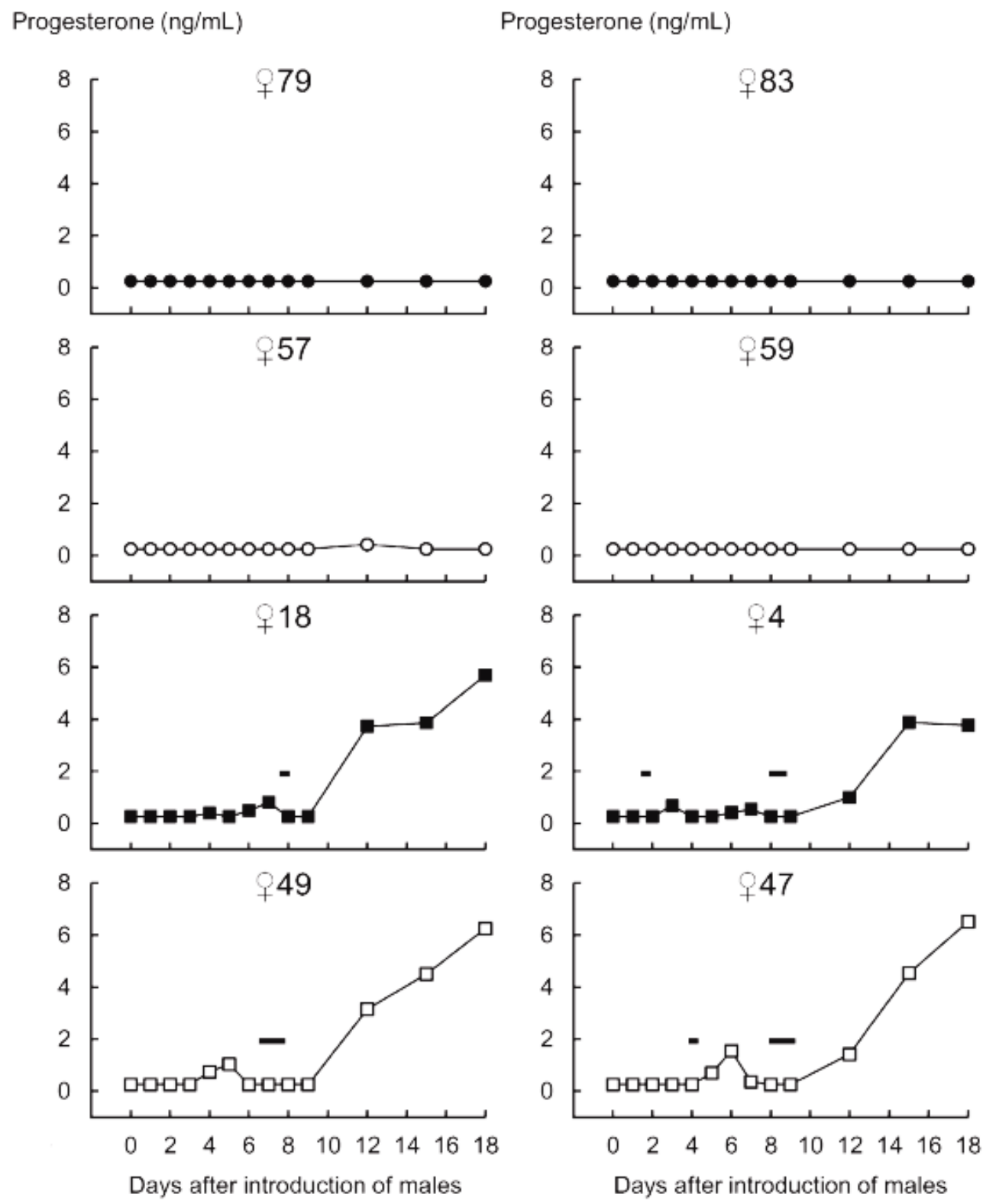


Our results showed that the exposition to novel males did not increase the sexual response of females, unless these males were sexually active. Indeed, most females displayed estrous behavior and ovulated when exposed to the photostimulated males, independently of whether they were familiar or novel. In contrast, no females displayed sexual activity when in contact with control males, independently of whether they were familiar or novel. Our results are not consistent with those reported in sheep, in which novelty of male stimulus is considered to be an important factor to stimulate the endocrine and sexual activities in ewes [13,14]. In fact, all ewes displayed a LH surge when they were exposed to novel males after 1 month of separation, whereas familiar males were able to induce a LH surge only in a third of females after the same period of separation [14]. Based on these later results, it was suggested that familiar rams might have become unfamiliar again after one month of separation from females [14]. However, this hypothesis was not validated here in goats, and seems in contradiction with results indicating that ewes are able to remember familiar individuals over very long periods of time ( $>2$ months; [11]). In the present study, even if males and females remained separated for 45 days after the familiarization period, control novel males did not trigger a better sexual response in females than familiar ones. The reasons for the difference between our results and those reported in sheep are not clear, but this difference could be related to species, breeds or to the fact that we used photostimulated males, which displayed an intense sexual activity $[3,6,37]$.

The importance of male sexual behavior in triggering endocrine and ovulatory responses in seasonally anovulatory female goats from subtropical regions has been well described in the literature. Indeed, this postulate is supported by several studies published by our group. Firstly, Delgadillo et al. [36] showed that females that remain with control males start their ovulatory activity in June, when males become sexually active. When females were exposed to photostimulated males, they started to ovulate before the onset of the natural breeding season, when males increased their sexual behavior. Secondly, it was shown that goats that remained in contact with males during three months ovulate when they are re-exposed to photostimulated, sexually active bucks, but not when they are re-exposed to control, sexually inactive ones [19]. Thirdly, in another study using goats of the same breed as used in the current study, none of them experienced a LH surge nor ovulation when exposed to sedated, photostimulated males, which emitted a strong odor but did not display any sexual behavior. In contrast, does exposed to intact, photostimulated males, which emitted a strong odor and displayed an intense sexual behavior, did so [38]. In the present study, the sexual behavior of the photostimulated males was more intense than that displayed by the control ones. Therefore, we can suppose that the photostimulated males were able to reactivate $\mathrm{GnRH} / \mathrm{LH}$ secretion, thus allowing ovulation; whereas the control males did not do so. Interestingly, the reactivation of the gonadotropic axis induced by the photostimulated males was independent of whether they were familiar or novel. Altogether, our results and those mentioned above indicate that, in goats, the sexual behavior displayed by males is more important than the familiarity between males and females in inducing the ovulatory activity in seasonally anestrous goats exposed to the male effect.

\section{Acknowledgments}

The authors are grateful to Enrique Antequera and Karla Ríos from Almerimex company for providing the female goats used in the Experiment 1; to Enrique Urquízo for providing the female goats used in the Experiment 2; and to Julio Salazar and Jesús García for taking care of the animals at the Centro de Investigación en Reproducción Caprina (CIRCA). We also thank Anne-Lyse Lainé and all the members of the platform of hormonal assay of the Laboratoire de Physiologie de la Reproduction et des Comportements of the INRA of Nouzilly, France, for carrying out the progesterone assay. We also express our thanks to all members of the CIRCA of the Universidad Autónoma Agraria Antonio Narro for 
their technical assistance, particularly to Jesús Vielma, Gerardo Duarte and Gonzalo Fitz-Rodríguez. We are grateful to Dolores López for their efficient secretarial and administrative assistance. A. L.Muñozwas supported by a scholarship of CONACYT during his doctoral studies (number of scholarship CVU372022). This work was supported by grants from the "Programa de Cooperación CONACYT" (México) Agence Nationale de la Recherche (France) 159884: "El efecto macho en ungulados: reproducción aplicada y mecanismos neuroendocrinos/ ANR Blanche Internationale France-Mexique" (11-ISV7-00101).

\section{References}

[1] G.B. Martin, C.M. Oldham, Y. Cognié, D.T. Pearce, The physiological response of anovulatory ewes to the introduction of rams. A review, Livest. Prod. Sci. 15 (1986) 219-247, http://dx.doi.org/10.1016/03016226(86)90031-X.

[2] P. Chemineau, Possibilities for using bucks to stimulate ovarian and oestrous cycles in anovulatory goats. A review, Livest. Prod. Sci. 17 (1987) 135-147, http://dx.doi.org/10.1016/0301-6226(87)90059-5.

[3] J.A. Delgadillo, H. Gelez, R. Ungerfeld, P.A.R. Hawken, G.B. Martin, The 'male effect' in sheep and goats-revisiting the dogmas, Behav. Brain Res. $200 \quad$ (2009) 304-314 http://dx.doi.org/10.1016/j.bbr.2009.02.004.

[4] B.J. Restall, Seasonal variation in reproductive activity in Australian goats, Anim. Reprod. Sci. 27 (1992) 305-318, http://dx.doi.org/10.1016/0378-4320(92)90145-4.

[5] J.A. Flores, F.G. Véliz, J.A. Pérez-Villanueva, G. Martínez de la Escalera, P. Chemineau, P. Poindron, et al., Male reproductive condition is the limiting factor of efficiency in the male effect during seasonal anestrus in female goats, Biol. Reprod. $62 \quad$ (2000) 14091414http://dx.doi.org/10.1095/biolreprod62.5.1409.

[6] A. Chanvallon, L. Sagot, E. Pottier, N. Debus, D. Francois, T. Fassier, New insights into the influence of breed and time of the year on the response of ewes to the 'ram effect', Animal 5 (2011) 1594-1604 http://dx.doi.org/10.1017/S1751731111000668.

[7] J. Vielma, P. Chemineau, P. Poindron, B. Malpaux, J.A. Delgadillo, Male sexual behavior contributes to the maintenance of high LH pulsatility in anestrous female goats, Horm. Behav. 56 (2009) 444-449 http://dx.doi.org/10.1016/j.yhbeh.2009.07.015.

[8] M. Bedos, G. Duarte, J.A. Flores, G. Fitz-Rodríguez, H. Hernández, J. Vielma, et al., Two or 24 h of daily contact with sexually active males results in different profiles of $\mathrm{LH}$ secretion that both lead to ovulation in anestrous goats, Domest. Anim. Endocrinol. 48 (2014) 93-99 http://dx.doi.org/10.1016/j.domaniend.2014.02.003.

[9] L.A. Zarazaga, I. Celi, J.L. Guzmán, B. Malpaux, Enhancement of the male effect on reproductive performance in female mediterranean goats with long day and/or melatonin treatment, Vet. J. 192 (2012) 441-444 http://dx.doi.org/10.1016/j.tvjl. 2011.09.012.

[10] N.M. Keil, S. Imfeld-Mueller, J. Aschwanden, B. Wechsler, Are head cues necessary for goats (Capra hircus) in recognising group members? Anim. Cogn. 15 (2012) 913-921http://dx.doi.org/10.1007/s10071012-0518-6. 
[11] K.M. Kendrick, A.P. Da Costa, A.E. Leigh, M.R. Hinton, J.W. Peirce, Sheep don't forget a face, Nature 414 (2001) 165-166.

[12] M. Keller, F. Cornilleau, E. Archer, F. Lévy, Development of social familiarity in ewes, Physiol. Behav. 104 (2011) 392-397 http://dx.doi.org/10.1016/j.physbeh.2011.04.030.

[13] P.A.R. Hawken, T. Jorre de St. Jorre, J. Rodger, T. Esmaili, D. Blache, G.B. Martin, Rapid induction of cell proliferation in the adult female ungulate brain (Ovis aries) associated with activation of the reproductive axis by exposure to unfamiliar males, Biol. Reprod. 80 (2009) 1146-1151 http://dx.doi.org/10.1095/biolreprod.108.075341.

[14] T. Jorre de St Jorre, P.A.R. Hawken, G.B. Martin, Role of male novelty and familiarity in maleinduced LH secretion in female sheep, Reprod. Fertil. Dev. 24 (2012) 523-530 http://dx.doi.org/10.1071/RD11085.

[15] C.M. Oldham, Y. Cognie, Do ewes continue to cycle after teasing? Proc. Aust. Soc. Anim. Prod. 13 (1980) 82-85.

[16] C.M. Oldham, Stimulation of ovulation in seasonally or lactationally anovular ewes by rams, Proc. Aust. Soc. Anim. Prod. 13 (1980) 73-74.

[17] J. Cohen-Tannoudji, J.P. Signoret, Effect of short exposure to the ramon later reactivity of anoestrous ewes to the male effect, Anim. Reprod. Sci. 13 (1987) 263-268, http://dx.doi.org/10.1016/03784320(87)90063-7.

[18] L. Gallego-Calvo, M.C. Gatica, I. Celi, J.L. Guzmán, J.A. Delgadillo, L.A. Zarazaga, No previous isolation of female goats is required for novel males to induce a male effect, especially if direct physical $\begin{array}{lllll}\text { contact is established, } & \text { Theriogenology } & \text { (2014) }\end{array}$ http://dx.doi.org/10.1016/j.theriogenology.2014.08.015.

[19] F.G. Véliz, P. Poindron, B.Malpaux, J.A.Delgadillo, Maintaining contact with bucks does not induce refractoriness to the male effect in seasonally anestrous female goats, Anim. Reprod. Sci. 92 (2006) 300309 http://dx.doi.org/10.1016/j.anireprosci.2005.06.006.

[20] Secretaría de Agricultura, Ganadería, Desarrollo Rural, Pesca y Alimentación, NORMA Oficial Mexicana NOM-062-ZOO-1999, Especificaciones técnicas para la producción, cuidado y uso de los animales de laboratorio, Diario Oficial de la Federación, México DF, 22 August 2001, 2001.

[21] G. Duarte, J.A. Flores, B. Malpaux, J.A. Delgadillo, Reproductive seasonality in female goats adapted to a subtropical environment persists independently of food availability, Domest. Anim. Endocrinol. 35 (2008) 362-370 http://dx.doi.org/10.1016/j.domaniend.2008.07.005.

[22] J.A. Delgadillo, G.A. Canedo, P. Chemineau, D. Guillaume, B.Malpaux, Evidence for an annual reproductive rhythm independent of food availability in male creole goats in subtropical northern Mexico, Theriogenology 52 (1999) 727-737, http://dx.doi.org/10.1016/S0093-691X(99)00166-1.

[23] R.H. Porter, L. Désiré, R. Bon, P. Orgeur, The role of familiarity in the development of social recognition by lambs, Behaviour 138 (2001) 205-219 http://dx.doi.org/10.1163/15685390151074384.

[24] J.A. Delgadillo, J.A. Flores, F.G. Véliz, H.F. Hernández, G. Duarte, J. Vielma, et al., Induction of sexual activity in lactating anovulatory female goats using male goats treated only with artificially long days, J. Anim. Sci. 80 (2002) 2780-2786. 
[25] R. Rivas-Muñoz, G. Fitz-Rodríguez, P. Poindron, B. Malpaux, J.A. Delgadillo, Stimulation of estrous behavior in grazing female goats by continuous or discontinuous exposure to males, J. Anim. Sci. 85 (2007) 1257-1263 http://dx.doi.org/10.2527/jas.2006-115.

[26] S.W. Walkden-Brown, B.J. Restall, R.J. Scaramuzzi, G.B. Martin, M.A. Blackberry, Seasonality in male Australian cashmere goats: long term effects of castration and testosterone or oestradiol treatment on changes in LH, FSH and prolactin concentrations, and body growth, Small Rumin. Res. 26 (1997) 239-252 http://dx.doi.org/10.1016/S0921-4488(97)00017-5.

[27] J. Vielma, P. Chemineau, P. Poindron, B. Malpaux, J.A. Delgadillo, Male sexual behavior contributes to the maintenance of high LH pulsatility in anestrous female goats, Horm. Behav. 56 (2009) 444-449 http://dx.doi.org/10.1016/j.yhbeh.2009.07.015.

[28] J.L. Ponce, H. Velázquez, G. Duarte, M. Bedos, H. Hernández, M. Keller, et al., Reducing exposure to long days from 75 to 30 days of extra-light treatment does not decrease the capacity of male goats to stimulate ovulatory activity in seasonally anovulatory females, Domest. Anim. Endocrinol. 48 (2014) 119125 http://dx.doi.org/10.1016/j.domaniend.2014.03.002.

[29] R. Gonzalez, P. Poindron, J.P. Signoret, Temporal variation in LH and testosterone responses of rams after the introduction of oestrous females during the breeding season, J. Reprod. Fertil. 83 (1988) 201-208 http://dx.doi.org/10.1530/jrf.0.0830201.

[30] C. Fabre-Nys, Le comportement sexuel des caprins: contrôle hormonal et facteurs sociaux, INRA Prod. Anim. 13 (2000) 11-23.

[31] S. Canépa, A.L. Lainé, A. Bluteau, C. Fagu, C. Flon, D. Monniaux, Validation d'une méthode immunoenzymatique pour le dosage de la progestérone dans le plasma des ovins et des bovins, Cah Tech INRA, 64 2008, pp. 19-30.

[32] J.A. Delgadillo, J.A. Flores, O. Villarreal, M.J. Flores, G. Hoyos, P. Chemineau, et al., Length of postpartum anestrus in goats in subtropical Mexico: effect of season of parturition and duration of nursing, Theriogenology 49 (1998) 1209-1218 http://dx.doi.org/10.1016/S0093-691X(98)00068-5.

[33] P. Chemineau, A. Daveau, F.Maurice, J.A. Delgadillo, Seasonality of estrus and ovulation is not modified by subjecting female alpine goats to a tropical photoperiod, Small Rumin. Res. 8 (1992) 299312 http://dx.doi.org/10.1016/0921-4488(92)90211-L.

[34] SYSTAT 13, 2009. Cranes Software International Ltd, San José, CA, USA

[35] J.L. Ponce, H. Velázquez, G. Duarte, M. Bedos, H. Hernández, M. Keller, et al., Reducing exposure to long days from 75 to 30 days of extra-light treatment does not decrease the capacity of male goats to stimulate ovulatory activity in seasonally anovulatory females, Domest. Anim. Endocrinol. 48 (2014) 119125 http://dx.doi.org/10.1016/j.domaniend.2014.03.002.

[36] J.A. Delgadillo, J.A. Flores, H. Hernández, P. Poindron, M. Keller, G. Fitz-Rodríguez, et al., Sexually active males prevent the display of seasonal anestrus in female goats, Horm. Behav. 69 (2015) 8-15 http://dx.doi.org/10.1016/j.yhbeh.2014.12.001.

[37] J.A. Delgadillo, J.A. Flores, G. Duarte, J. Vielma, H. Hernández, M. Bedos, et al., Out-of-season control of reproduction in subtropical goats without exogenous hormonal treatments, Small Rumin. Res. 121 (2014) 7-11 http://dx.doi.org/10.1016/j.smallrumres.2014.01.011. 
[38] J.C. Martínez-Alfaro, H. Hernández, J.A. Flores, G. Duarte, G. Fitz-Rodríguez, I.G. Fernández, et al., Importance of intense male sexual behavior for inducing the preovulatory LH surge and ovulation in seasonally anovulatory female goats, Theriogenology 82 (2014) 1028-1035 http://dx.doi.org/10.1016/j.theriogenology.2014.07.024. 